\title{
PATHOGENIC ORGANISMS ON SPRING BARLEY IN THE EASTERN FOREST-STEPPE OF UKRAINE
}

Zviahintseva A.M., Petrenkova V.P., Kobyzeva L.N., Nyska I.M., Kucherenko Ye.Yu., Zuieva K.V., Vasko N.I.

Plant Production Institute named after V.Ya. Yuriev NAAS, Ukraine

\section{Key words: pathogens, spring barley, barley frit fly, oat frit fly, Drechslera root rot, barley leaf stripe disease, head smut, alternaria leaf spot, Fusarium rot, seed infection}

Introduction. Spring barley is a leading food crop at the world market, ranking fourth among cereals in terms of sown area [1]. Spring barley is suitable for growing in all climatic zones of Ukraine and, provided intensive technologies, gives a grain yield of 5-8 t/ha [2]. Currently, measures for spring barley growing do not provide the desired yields due to violations of cultivation technologies [3]. Among the factors limiting the barley grain yield and quality in the country, there is farmers' inattention to protection of crops against harmful organisms. This is primarily attributed to the inadequate awareness of farmers about changes occurring in spring barley agrocenoses because of simultaneous impact of anthropogenic activities and weather conditions.

At present, the climate is changing all over the world [4]. In Ukraine, the climate also tends to change: there are sharp fluctuations in precipitation periods and a significant increase in temperature in most regions of the country [5]. Recently, the climate in the Eastern Forest-Steppe has been noticeable for a drastic differential in precipitation and an upward trend in the average daily air temperature. Climate changes are closely associated with to the level of disease-induced damage to plant, as the environment significantly affects plants, pathogens and their vectors [6]. Hence, climate changes affect not only the plant vegetation length, but also the dynamics of harmful organism development on agricultural crops, including spring barley.

In addition to the climate, the phytosanitary situation on spring barley crops is also affected by changes in the structure of sown areas and in cultivation technologies [7]. For example, simplification of crop rotations without taking into account the traditional basics and rules of crop rotation leads to the threatening spread of specialized weeds, pests and diseases, despite the growing use of protective chemicals in Ukraine [8]. Each crop generally has specific diseases and pests, and prolonged cultivation of one crop in the same location contributes to accumulation of infections and pests in the field [9].

Therefore, studies of pathogens on crops, including spring barley, in specific climatic zones are becoming of immediate interest, which is important both for development of highly effective protective measures and for breeding for plant resistance to pathogens and pests. Agrobiocenosis monitoring enables not only managing the consequences of application of current protective measures, but also planning the breeding process to create resistant and highly adaptable varieties.

Studies conducted in the Laboratory of Plant Immunity to Diseases and Pests of the Plant Production Institute named after V.Ya. Yuriev NAAS address phytosanitary diagnostics, which combines a number of problems to reduce the impact of pathogens on the plant growth and development as well as on the yield, including phytosanitary monitoring, determining the prevalence of harmful organisms, pathogenicity of strains and virulence of races, finding sources of resistance, evaluating their genetic potential to create spring barley varieties with group and complex resistance to biotic factors.

(C) A.M. Zviahintseva, V.P. Petrenkova, L.N. Kobyzeva, I.M. Nyska, Ye.Yu. Kucherenko,

K.V. Zuieva, N.I. Vasko. 2020.

ISSN 1026-9959. Селекція і насінництво. 2020. Випуск 118. 
Material and methods. Mycological, microscopic, statistical, phytopathological and entomological field and laboratory methods were used to achieve this purpose in 2009-2017. We used visual methods to assess diseases and pests, which are based on direct inspection of plants and visual determination of their damage intensity or damage in accordance with the conventional assessment scales and methods modified by us in the course of work [10-13].

To improve the methods of determining the species of harmful organisms on spring barley, seeds were sown in two seasons: in spring (optimal timeframe) and autumn (provocative) with subsequent measurement of the affection of plants by pathogens causing leaf and root diseases as well as by intrastem pests during the tillering phase.

To determine the fungal contamination of barley grain, we developed the method, which consists in caryopsis germination in sucrose solution in a humid chamber under constant light, accelerating the manifestation of disease signs on infected grain. Petri dishes were pre-sterilized in a thermostat at $150^{\circ} \mathrm{C}$ for 2 hours. $13.1 \mathrm{~g}$ of sucrose was dissolved in distilled water under an osmotic pressure of 12 atmospheres, and then the solution was carefully boiled for 5 minutes to avoid evaporation of the liquid. Spring barley seeds were laid out, hila upwards, 25 seeds per Petri dish in four replications. $5 \mathrm{ml}$ of sucrose solution was poured into each dish. Seeds germinated for $4-5$ days at $22^{\circ} \mathrm{C}$. Such conditions favor conidial sporulation of fungi. Infected seeds were examined under a MBS-9 binocular microscope at 24-fold magnification.

The contamination percentage was calculated by the formula (1):

$\mathrm{C}=\mathrm{Ni} * 100 / \mathrm{Ne} \quad(1)$;

where $\mathrm{C}$ - percentage of contamination of spring barley caryopses, $\%$;

$\mathrm{Ni}$ - number of infected caryopses;

$\mathrm{Ne}-$ number of examined caryopses.

To characterize the weather and climatic conditions during the growing period, we used data of Kharkiv Regional Center for Hydrometeorology on air temperature and precipitation. Humidification during the spring barley growing period was described with the hydrothermal coefficient (HTC) [14].

Eleven modern spring barley varieties, which are suitable for dissemination in Ukraine, 12 promising breeding lines from the Laboratory of Barley Breeding of the Plant Production Institute named after V.Ya. Yuriev NAAS and 150 collection accessions from the National Center for Plant Genetic Resources of Ukraine (NCPGRU) of the Institute of Plant Production Institute named after V.Ya. Yuriev NAAS originating from 15 countries were investigated. Seeds of varieties, lines and collection accessions were sown in the same field, with a plot area of $1 \mathrm{~m}^{2}$. References of susceptibility to pathogens and intrastem pests were sown every 10 accessions to accumulate infections and pests in the crop. The experimental plots were surrounded by a continuous band from a seed mixture of varieties that are common in the region. The total field area was 0.5 hectares. The forecrop was winter wheat. Seeds were not dressed before sowing, and plants were not treated with pesticides during the growing period.

Results and discussion,. The prevalence of two Drechslera infections on spring barley crops was determined, in particular of $D$. teres Ito, which causes barley net blotch , and of $D$. sorokiniana Subram, which causes root rot. In addition, two species of corn flies were identified: oat (Oscinella frit Linnaeus) and barley (O. pusilla Meigen) frit flies. Autumn sowing in comparison with the traditional method of spring sowing proved to be a more effective way to assess the response of spring barley varieties, lines and collection accessions to pathogens, in particular Drechslera species. Thus, the prevalence of diseases on spring barley crops sown in spring was on average across the study years $15.9 \%$ of plants affected $D$. teres Ito and $42.7 \%$ of plants affected by $D$. sorokiniana Subram (Table 1). Upon autumn sowing, the prevalence of these diseases was higher and amounted to $38.7 \%$ and $45.2 \%$ of affected plants, respectively.

However, autumn sowing was less effective for assessments of accessions for damage induced by oat and barley frit flies, because the larva populations on the autumn crops were twice as small as the corresponding populations on the spring crops, indicating a possibility of using autumn sowing only as an additional method to detect harmful organisms in the field. In addition to phytopathological and entomological assessments of spring barley crops, autumn sowing also makes prediction of the harmful organism development on spring barley in the spring-summer season possible. 
Table 1

The prevalence of diseases and pests on spring barley crops assessed by different methods

\begin{tabular}{lccccc}
\hline \multirow{2}{*}{ Method } & Year & $\begin{array}{c}\text { Affected/damaged plants, \% } \\
\text { barley net } \\
\text { blotch }\end{array}$ & $\begin{array}{c}\text { Drechslera } \\
\text { root rots }\end{array}$ & Frit flies & $\begin{array}{c}\text { HTC during } \\
\text { the growing } \\
\text { period }\end{array}$ \\
\hline \multirow{4}{*}{ Spring sowing } & 2010 & 15.5 & 34.6 & 55.1 & 0.6 \\
& 2011 & 17.3 & 60.0 & 53.9 & 1.4 \\
& 2012 & 14.9 & 33.5 & 54.3 & 0.4 \\
& Mean & 15.9 & 42.7 & 54.4 & - \\
\hline \multirow{5}{*}{ Autumn sowing } & 2009 & 50.6 & 35.8 & 38.3 & 0.5 \\
& 2010 & 32.9 & 43.5 & 18.5 & 3.5 \\
& 2011 & 33.1 & 64.2 & 32.7 & 0.6 \\
& 2012 & 38.2 & 37.4 & 19.3 & 1.1 \\
& Mean & 38.7 & 45.2 & 27.2 & - \\
\hline
\end{tabular}

During the next eight study years (2013-2020), of diseases, head smut (Ustilago hordei (Pers. Lagerh.), net blotch (D. teres Ito), leaf stripe (D. graminea (Rabenh.) Shoemaker) and spot blotch (D. sorokiniana Subram) became widespread (Fig. 1$)$; of pests, corn flies $(O$. frit Linnaeus and $O$. pusilla Meigen) remained most common (Table 2). The levels of pathogen- and pest-induced damage to plants during the study years ranged $21 \%$ to $67 \%$ of affected plants (head smut; artificial infection); $25 \%$ to $100 \%$ (Drechslera spot diseases); and $39 \%$ to $100 \%$ (corn flies; provocative background).

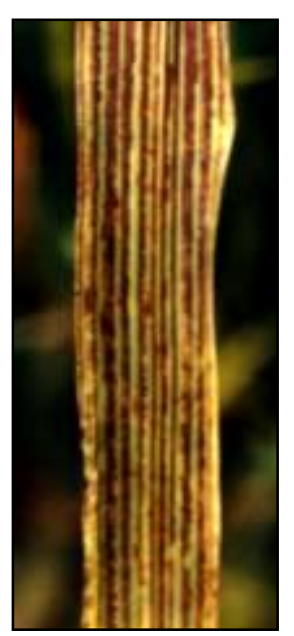

$\mathrm{a}$

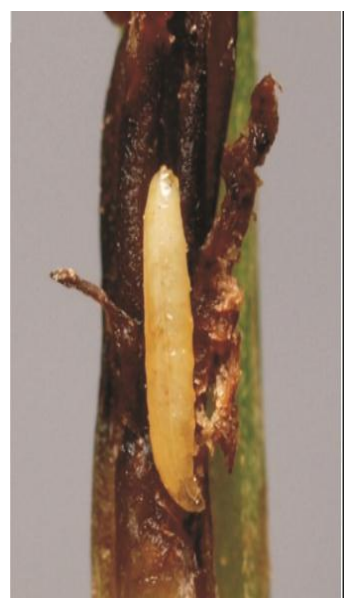

a

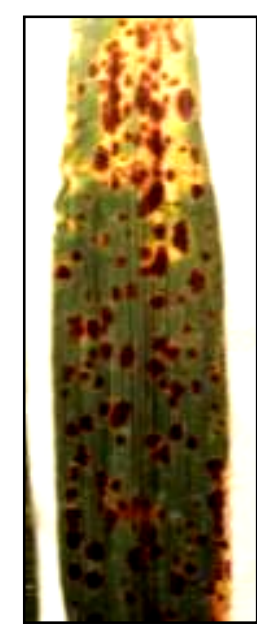

b

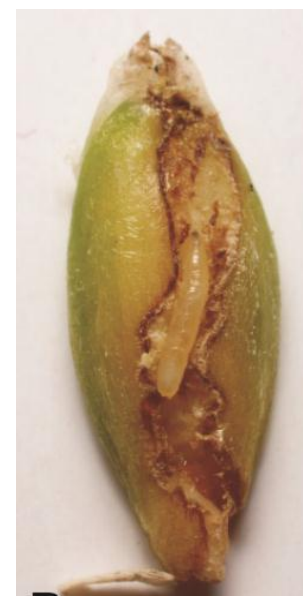

b

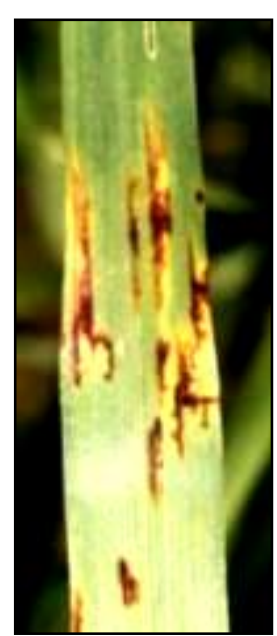

c
Fig.1. Drechslera spot diseases of spring barley: a) leaf stripe, b) spot blotch, c) net blotch.
Fig. 2. Plants damaged by corn flies:

a) larva inside a stem,

b) larva on a caryopsis,

c) shoot withering. 
During the eight-year study, the highest prevalence of head smut (up to 67\%) was observed in 2015 and 2020, when the weather (judging from the hydrothermal coefficient) was excessively humid during the spring barley growing period (HTC $=1.7$ in 2020) or slightly arid $($ HTC $=1.1$ in 2015). The disease development was moderate $(25 \%, 42.1 \%)$ in 2014 and 2016, when the hydrothermal coefficient was optimal (1.4 and 1.3, respectively). Under the very arid conditions $(2017$; HTC $=0.5)$, we observed a weak development of head smut $(21 \%)$.

The prevalence of Drechslera spot diseases on spring barley plants differed, depending on the year. The greatest spread of Drechslera spot diseases (100\%) was observed on sufficient moisture in 2014, when the HCT during the barley growing period was 1.4. Under very and slightly arid conditions ( $\mathrm{HTC}=0.7$ and 1.3) in 2013 and 2016, respectively, the disease development became epiphytic $-63.0-65.0 \%$, respectively. The disease also progressed actively (70\%) on excessive moisture in $2020(\mathrm{HTC}=1.7)$. The disease progressed moderately in $2015(32.0 \%)$ under slightly arid conditions (HTC 1.1) and in $2017(25.0 \%)$ under very arid conditions (HTC $=0.5)$.

Table 2

Variability of harmful organisms on spring barley

\begin{tabular}{|c|c|c|c|c|}
\hline \multirow[b]{2}{*}{ Year } & \multicolumn{3}{|c|}{ Affected/damaged plants, $\%$} & \multirow[b]{2}{*}{ HTC } \\
\hline & Head smut & $\begin{array}{c}\text { Drechslera spot } \\
\text { diseases }\end{array}$ & Corm flies & \\
\hline 2013 & 52 & 63 & 96 & 0.7 \\
\hline 2014 & 25 & 100 & 47 & 1.4 \\
\hline 2015 & 65 & 32 & 40 & 1.1 \\
\hline 2016 & 43 & 65 & 39 & 1.3 \\
\hline 2017 & 21 & 25 & 44 & 0.5 \\
\hline 2018 & 25 & 67 & 59 & 0.4 \\
\hline 2019 & 40 & 65 & 100 & 0.9 \\
\hline 2020 & 67 & 70 & 67 & 1.7 \\
\hline Mean & 42 & 61 & 62 & - \\
\hline
\end{tabular}

Although the HTC in the study years ranged 0.4 to 1.7 , i.e. the weather ranged from very arid to excessively humid, the frit flies were numerous, only in 2016 the pest number decreased to $39 \%$. This can be attributed to the fact that the barley frit fly belongs to xerophilous pests, and arid conditions are favorable for it $(\mathrm{HTC}=0.4-1.1)$, namely 2013, 2015, 2017, 2018 and 2019, but the oat fit fly is a hygrophilous pest and thrives better in humid years $(\mathrm{HTC}=1.3-1.7)-$ 2014, 2016 and 2020.

Analysis of the contamination of spring barley grain harvested in 2014-2016 with fungal pathogens revealed that the germination of spring barley seeds in sucrose solution stimulated the progress of fungal diseases, accelerated the manifestation of signs on infected seeds and enabled obtaining reliable data on the contamination without additional efforts. Basing on this, we developed a method for determining the contamination of spring barley grain (Patent UA 67887 U IPC A01H 1/04 (2006.01), effective from 01.09.2018). Using this method, we determined that in the Eastern Forest-Steppe of Ukraine diseases caused by fungi of the genera D. spp., Fusarium Link. and Altenararia Fries. were the major pathogens spreading on spring barley seeds. Thus, Alternaria-caused affection of seeds of collection spring barley accessions ranged 9.0-77.0\%; Drechslera-caused affection -4.0 to $55.0 \%$; Fusarium-caused affection -0.0 to $12.4 \%$. Therefore, to prevent the disease progress during the initial stages of plant ontogenesis in production conditions, pre-sowing treatment of seeds is necessary.

Discussion. Thus, head smut, Drechslera spot diseases (net blotch, leaf stripe, spot blotch) and Drechslera root rots are the most common and harmful diseases of spring barley in the Eastern Forest-Steppe of Ukraine. Yield losses from these pathogens range from 15\% to $50 \%$ in epiphytic years (Table 3) [15].

Review of other researchers' data published for the last 15 years shows that fungal diseases have become widespread on barley crops not only in Ukraine, but also in other countries. For 
example, in Great Britain, especially in Western England and Scotland, scald (Rhynchosporium secalis Oud.) [16-18] causes significant damage to barley crops, in South America (Brazil, Argentina) net blotch (D. teres Ito) is widespread. [19], in Germany ramularia leaf spot (Ramularia collo-cygni Suton \& Waller) is quite frequent [20]. Development of measures to manage barley brown rust (Puccinia hordei Otth.) is an urgent problem in Australia, India and the United States [21].

With active progress of pathogens on barley crops, the effectiveness of fungicides is not always high. In addition, researchers of the VM Remeslo Myronivka Institute of Wheat NAAS reported that damage to leaves from pathogens causing spots was difficult to compensate, because, when they are widespread, they lead to a rapid death of the leaf surface [22]. Therefore, it is advisable to grow varieties that are resistant to the above pathogens.

Fungi of the genera Drechslera spp., Fusarium Link. and Altenararia Fries are also found on spring barley caryopses. It is interesting that a similar group of pathogens was detected on spring barley grain earlier by researchers from Oman, a country in the tropical climate zone [23], indicating that these diseases are spread on a significant area.

Table 3

\begin{tabular}{lc}
\multicolumn{2}{c}{ Loss of the spring barley yield from plant affection by common pathogens in the Eastern } \\
\multicolumn{1}{c}{ Forest-Steppe of Ukraine } \\
\hline Disease & Loss of yield, \% \\
\hline Head smut & $\geq 15-20$ \\
Net blotch & $33-50$ \\
Leaf stripe & $\leq 30$ \\
Spot blotch & $30-40$ \\
Drechslera root rots & $\leq 40$ \\
\hline
\end{tabular}

Frit flies, - oat frit fly (O. frit Linnaeus) and barley frit fly (O. pusilla Meigen), are dangerous pests of spring barley in the Eastern Forest-Steppe of Ukraine. Other researchers reported that these species of corn flies were common not only in the Eastern Forest-Steppe, but also throughout the entire climatic zone, causing damage to many cereals. For example, scientists from the National University of Life and Environmental Sciences observed the spread of frit flies in all experiments conducted in the Forest-Steppe of Ukraine [24]. However, there reports that the oat frit fly was more numerous in the Western Forest-Steppe. This species is more moistureloving and less thermophilic compared to the barley frit fly. Invasion of barley crops by intrastem pests is especially dangerous, because due to the latebrosus life style of pests and long flight time of adult flies, chemicals are not effective in most cases, hence, the plant protection priority against corn flies is spring barley breeding for resistance to intrastem pests.

Conclusions. Via the phytopathological and entomological monitoring of spring barley crops in the Eastern Forest-Steppe of Ukraine, the pathogen species causing economic losses (15$40 \%$ of yield) upon this crop cultivation were identified. Head smut (U. hordei (Pers. Lagerh.), leading to $15-20 \%$ reduction in the yield, and Drechslera diseases affecting both aerial parts of plants (D. teres Ito, D. graminea (Rabenh.) Shoemaker) and the root system of plants (D. sorokiniana Subram) and leading to 33-50\% in the yield are the most common diseases of spring barley in this climatic zone. Frit flies, i.e. oat frit fly (O. frit Linnaeus) and barley frit fly (O. pusilla Meigen) with larvae's latebrosus life style and imagoes' long flight period, complicating chemical protection of crops, are dangerous pests. Pathogens that develop on spring barley caryopses are fungi of the genera Drechslera spp., Fusarium Link. and Altenararia Fries., which can cause root rot, crop thinning and plant infection. Two new methods of phytopathological monitoring of spring barley crops have been developed: one of them is carried out by autumn sowing of seeds and provides additional analysis of the pathogen presence on crops in one study year, and the 
other accelerates detection of seed infections by germination of caryopses in sucrose solution under constant light.

Thus, a comprehensive monitoring system of the prevalence of harmful organisms growing on spring barley roots, stems, leaves, ears and caryopses provides detection of changes in the phytosanitary condition of crops, elucidation of their causes, prediction of intensity of disease and pest spreading and timely adoption of protective measures.

Adherence to ethical standards. The studies were conducted in accordance with the objectives of the thematic plan of the Laboratory of Plant Immunity to Diseases and Pests, which were part of the Scientific-Technical Program "Cereals" in 2006-2010. There is no conflict of interest. The projects pursuing by the author team were funded from the state budget of Ukraine.

\section{References}

1. Muzafarova VA, Riabchun VK, Petukhova IA, Padalka OI. Peculiarities of the yield capacity of spring barley gene pool accessions in the eastern of forest-steppe of Ukraine. Sel. i Nasinn. 2018; 113: 111-124. DOI: 10.30835/2413-7510.2018.137291.

2. Agriculture of Ukraine. Statistical Yearbook. Kyiv, 2018: 102-103.

3. Rozhkov AO, Chernobay SV. Yield capacity of spring barley variety Dokuchaievskyi 15, depending upon application of various seeding rates and additional foliar fertilizers. Visnyk Poltavskoyi Derzhavnoyi Akademii. 2014; 4: 30-34. DOI: 10.31210/visnyk/.

4. Chakraborty S, Newton AC. Climate change, plant diseases and food security, an overview. Plant Pathology. 2011; 60: 2-14. DOI: 10.1111/j.1365-3059.2010.02411.x.

5. Boychenko S, Voloshchuk V, Movchan Ya, Serdjuchenko N, Tkachenko V, Tyshchenko O, Savchenko S. Features of climate change on Ukraine: scenarios, consequences for nature and agroecosystems. Proc. of the National Aviation University. 2016; 4(69): 96-113. DOI: 10.18372/2306-1472.69.11061.

6. Mishchenko L, Dunich A, Mishchenko I, Berlizov V, Petrenkova V, Molchanets O. Influence of climate changes on wheat viruses variability in Ukraine. Agriculture and Forestry. 2017; 63(4): 43-50. DOI: 10.17707/AgricultForest.63.4.04.

7. Onychko VI, Kovalenko OA. Monitoring of species composition of pests and pathogens on spring cereal crops in the north-eastern forest-steppe of Ukraine. Visnyk Sumskoho Natsionalnoho Ahrarnoho Universytetu. Series Ahronomia i Biolohia. 2012; 9(24): 19-21.

8. Shuvar IA, Binert BI, Ivaniuk VYa. Short crop rotations. Ahrobiznes Siohodni. 2015; 5(300). http://agro-business.com.ua/agro/ahronomiia-sohodni/item/535-korotkorotatsiini-sivozminy-tabezzminno.html.

9. Kudria SO. Performance of crop rotation components on typical black soils of the Left-Bank Forest-Steppe. Naukovi Dopovidi NUBiP Ukrainy. 2018; 3(73). DOI: 10.31548/dopovidi2018.03.008.

10. Babayants LT, Meshterkhazi A, Vekhter F et al. Methods of breeding and evaluation of wheat and barley for resistance to diseases. Prague, 1988. $321 \mathrm{p}$.

11.Petrenkova VP, Borovska IYu, Luchna IS, Sokol TV, Babushkina TV, Chuhaiev SV, Zviahintseva AM, Baranova VV, Nyska IM. Methods of field crop collection formation by resistance to biotic factors. Kharkiv, 2015. $111 \mathrm{p}$.

12.Zagovora AV. Entomological evaluation of breeding material of cereals and grain legumes. Kharkov, 1980. $61 \mathrm{p}$.

13. Geshele EE. Methodological guide to phytopathological evaluation of cereals. Odessa, 1971. $180 \mathrm{p}$.

14.Losev AP, Zhurkina LL. Agrometeorology. M.: Kolos, 2001. 301 p.

15. Makarova MA, Shevtsova AI, Semenova LG. Characterization of maize and spring barley genepool in terms of phytopathogen resistance in the Amur River region. Dalnevostochnyy Agrarnyy Vestnik. 2018; 2(46): 25-31. DOI: 10.24411/1999-6837-2018-12024.

16. Atkins SD, Fitt BD, Fraaije B, Harvey S, Lynott J, Newton AC. The epidemiological importance of asymptomatic infection of winter barley by Rhynchosporium secalis and its con- 
sequences for crop protection and breeding. Proceedings Crop Protection in Northern Britain - Dundee, United Kingdom, 2010. P. 81-86.

17. Cooke LR, Locke T, Lockley KD, Phillips A, Sadiq MDS, Coll R, Black L, Taggart PJ, Mercer PC. The effect of fungicide programmes based on epoxiconazole on the control and DMI sensitivity of Rhynchosporium secalis in winter barley. Crop Protection. 2004; 23: 393-406. DOI: 10.1016/j.cropro.2003.09.009.

18. Fountaine JM, Shaw MW, Ward E, Fraaije $B A$. The role of seeds and airborne inoculum in the initiation of leaf blotch (Rhynchosporium secalis) epidemics in winter barley. Plant Pathology. 2010; 59: 330-337. DOI: 10.1111/j.1365-3059.2009.02213.x.

19. Carmona M, Barreto D, Moschini R, Reis E. Epidemiology and control of seed borne Drechslera teres on barley. Cereal Research Communications. 2008; 36: 637-645. DOI: 10.1556/CRC.36.2008.4.13.

20. Stam R, Sghyer H, Tellier A, Heß M, Hückelhoven R. The current epidemic of the barley pathogen Ramularia collo-cygni derives from a recent population expansion and shows global admixture. Phytopathology. 2019. DOI: 10.1094/PHYTO-04-19-0117-R.

21.Park RF, Golegaonkar PG, Derevnina L, Sandhu KS, Karaoglu H, Elmansour HM, Dracatos PM, Singh D. Leaf rust of cultivated barley: pathology and control. Annual Review of Phytopathology. 2015; 53: 565-589. DOI: 10.1146/annurev-phyto-080614-120324.

22. Hudzenko VM, Vasylkivskyi SP. Main lines and objectives in winter barley breeding in the Central Forest-Steppe of Ukraine. Novitni Ahrotekhnolohii. 2016; 1(4). DOI: 10.21498/na.1(4).2016.118001.

23. Al-Sadi AM, Deadman ML. Influence of seed-borne Cochliobolus sativus (Anamorph Bipolaris sorokiniana) on crown rot and root rot of barley and wheat. Journal of Phytopthology. 2010; 158(10): 683-690. DOI: 10.1111/j.1439-0434.2010.01684.x.

24. Sakhnenko VV, Sakhnenko DV, Varchenko TP. Modern systems of resource-saving measures to protect winter wheat and corn against pests in the Forest-Steppe of Ukraine. Naukovi Dopovidi NUBiP Ukrainy. 2018; 4(74). DOI: 10.31548/dopovidi2018.04.011.

\section{Список використаних джерел}

1. Музафарова В.А., Рябчун В.К., Петухова І.А., Падалка О. І. Особливості формування врожайності зразків генофонду ячменю ярого в умовах східної частини Лісостепу України. Селекція і насінництво. 2018. Вип. 113. С. 111-124. DOI: 10.30835/24137510.2018 .137291$.

2. Сільське господарство України. Статистичний щорічник. Київ, 2018. С. 102-103.

3. Рожков А.О., Чернобай С.В. Урожайність ячменю ярого сорту Докучаєвський 15 залежно від застосування різних норм висіву та позакореневих підживлень. Вісник Полтавської державної академії. 2014. № 4. С. 30-34. DOI: 10.31210/visnyk/.

4. Chakraborty S., Newton A.C. Climate change, plant diseases and food security, an overview. Plant Pathology. 2011; 60: 2-14. DOI: 10.1111/j.1365-3059.2010.02411.x.

5. Бойченко С., Волощук В., Бовчан Я., Сердюченко Н., Ткаченко В., Тищенко О., Савченко С. Особливості кліматичних змін в Україні: сценарії, наслідки для природи та агроекосистем. Proc. of the National Aviation University. 2016. Вип. 4(69). С. 96-113. DOI: $10.18372 / 2306-1472.69 .11061$.

6. Mishchenko L., Dunich A., Mishchenko I., Berlizov V., Petrenkova V., Molchanets O. Influence of climate changes on wheat viruses variability in Ukraine. Agriculture and Forestry. 2017; 63(4): 43-50. DOI: 10.17707/AgricultForest.63.4.04.

7. Оничко В.І., Коваленко О.А. Моніторинг видового складу шкідників і хвороб на посівах ярих зернових культур в умовах північно-східного Лісостепу України. Вісник Сумського Національного аграрного університету. Серія Агрономія і Біологія. 2012. Вип. 9(24). С. $19-21$.

8. Шувар І.А., Бінерт Б.І., Іванюк В.Я. Короткоротаційні сівозміни та беззмінно. Агробізнес сьогодні. 2015. № 5(300). http://agro-business.com.ua/agro/ahronomiiasohodni/item/535-korotkorotatsiini-sivozminy-ta-bezzminno.html. 
9. Кудря С.О. Продуктивність ланок сівозмін на типових чорноземах лівобережного Лісостепу. Наукові доповіді НУБіП України. 2018. № 3(73). DOI: 10.31548/dopovidi2018.03.008.

10. Бабаянц Л.Т., Мештерхази А., Вехтер Ф. и др. Методика селекции и оценки пшеницы и ячменя на устойчивость к болезням. Прага, 1988. $321 \mathrm{c.}$

11. Петренкова В.П., Боровська І.Ю., Лучна І.С., Сокол Т.В., Бабушкіна Т.В., Звягінцева А.М., Баранова В.В., Ниска I.М. Методи формування колекції польових культур шляхом стійкості до біотичних факторів. Харків, 2015. $111 \mathrm{c.}$

12. Заговора А.В. Ентомологічна оцінка селекційного матеріалу зернових та зернобобових культур. Харків, 1980. 61 с.

13. Гешеле Е.Е. Методическое пособие по фитопатологической оценке зерновых культур. Одесса, 1971. 180 с.

14. Лосев А.П., Журкина Л.Л. Агрометеорология. М.: Колос, 2001. 301 с.

15. Макарова М.А., Шевцова А.И., Семенова Л.Г. Характеристика генофонда кукурузы и ярового ячменя по устойчивости к фитопатогенам в Приамурье. Дальневосточный Аграрный вестник. 2018. № 2(46). С. 25-31. DOI: 10.24411/1999-6837-2018-12024.

16. Atkins S.D., Fitt B.D., Fraaije B., Harvey S., Lynott J., Newton A.C. The epidemiological importance of asymptomatic infection of winter barley by Rhynchosporium secalis and its consequences for crop protection and breeding. Proceedings Crop Protection in Northern Britain - Dundee, United Kingdom, 2010. P. 81-86.

17. Cooke L.R., Locke T., Lockley K.D., Phillips A., Sadiq M.D.S., Coll R., Black L., Taggart P.J., Mercer P.C. The effect of fungicide programmes based on epoxiconazole on the control and DMI sensitivity of Rhynchosporium secalis in winter barley. Crop Protection. 2004. № 23. P. 393-406. DOI: 10.1016/j.cropro.2003.09.009.

18. Fountaine J.M., Shaw M.W., Ward E., Fraaije B.A. The role of seeds and airborne inoculum in the initiation of leaf blotch (Rhynchosporium secalis) epidemics in winter barley. Plant Pathology. 2010. № 59. P. 330-337. https://doi.org/10.1111/j.1365-3059.2009.02213.x.

19. Carmona M., Barreto D., Moschini R., Reis E. Epidemiology and control of seed borne Drechslera teres on barley. Cereal Research Communications. 2008. № 36. P. 637-645. DOI: 10.1556/CRC.36.2008.4.13.

20. Stam R., Sghyer H., Tellier A., Heß M., Hückelhoven R. The current epidemic of the barley pathogen Ramularia collo-cygni derives from a recent population expansion and shows global admixture. Phytopathology. 2019. DOI: 10.1094/PHYTO-04-19-0117-R.

21. Park R.F., Golegaonkar P.G., Derevnina L., Sandhu K.S., Karaoglu H., Elmansour H.M., Dracatos P.M., Singh D. Leaf rust of cultivated barley: pathology and control. Annual Review of Phytopathology. 2015. № 53. P. 565-589. DOI: 10.1146/annurev-phyto-080614-120324.

22. Гудзенко В.М., Васильківський С.П. Основні напрями та завдання селекції ячменю озимого у Центральному Лісостепу України. Novitni Ahrotekhnolohii. 2016. № 1(4). DOI: $10.21498 /$ na.1(4).2016.118001.

23. Al-Sadi A.M., Deadman M.L. Influence of seed-borne Cochliobolus sativus (Anamorph Bipolaris sorokiniana) on crown rot and root rot of barley and wheat. Journal of Phytopthology. 2010. № 158(10). P. 683-690. DOI: 10.1111/j.1439-0434.2010.01684.x.

24. Сахненко В.В., Сахненко Д.В., Варченко Т.П. Сучасні системи ресурсоощадних заходів захисту пшениці озимої та кукурудзи від шкідників в Лісостепу України. Наукові доповіді НУБіП України. 2018. № 4(74). DOI: 10.31548/dopovidi2018.04.011. 


\section{ПАТОКОМПЛЕКС ЯЧМЕНЮ ЯРОГО В СХІДНЙ ЧАСТИНІ ЛІСОСТЕПУ УКРӒ̈НИ}

Звягінцева А.М., Петренкова В.П., Кобизєва Л.Н., Ниска І.М., Кучеренко Є.Ю., Зуєва К.В., Васько Н.I.

Інститут рослинництва імені В.Я. Юр'єва НААН, Україна

Мета. Визначити комплекс шкідливих організмів ячменю ярого та їх мінливість під впливом гідротермічних умов вегетаційного періоду культури в східній частині Лісостепу України та удосконалити способи виявлення видового складу хвороб на рослинах та зерні.

Методи. Рівень поширеності хвороб та шкідників визначали згідно загальноприйнятих та спеціальних методик у відповідності до існуючих шкал оцінки та методик, модифікованих нами у ході роботи. Удосконалювали способи визначення видового складу збудників хвороб ячменю ярого шляхом весняного (оптимальний) та осіннього (імітація вологих умов) висіву насіння 3 наступним проведенням обліку прояву хвороб у фазі кущіння рослин та підбором живильного середовища для фітоекспертизи зерна і визначення рівня його зараженості.

Результати. Внаслідок проведення обліків щодо поширеності хвороб і шкідників на рослинах ячменю ярого впродовж 2009-2020 рр. при різних строках сівби насіння (восени та навесні) встановлено, що осіння сівба насіння $є$ більш ефективним способом для прояву гельмінтоспоріозів на ячмені ярому порівняно із загальноприйнятим способом весняної сівби, так як в осінній період створюються сприятливі умови для розвитку цього гриба. В основному патокомлекс ячменю ярого був представлений кам'яною сажкою, гельмінтоспоріозними плямистостями листя, кореневими гнилями, злаковими мухами. Найбільше поширення кам'яної сажки (до 67,0 \%) відмічали в роки, коли погодні умови періоду вегетації характеризувались як надмірно зволожені (ГТК $=1,7$ в 2020 р.) і слабко посушливі (ГТК $=1,1$ в 2015 р.). Найвище значення розповсюдження гельмінтоспоріозних плямистостей (100 \%) відмічено в умовах достатнього зволоження в 2014 році $(Г Т К=1,4)$. Чисельність шведських мух за період досліджень перебувала, в основному, на значному рівні (до $100 \%$ ), тільки в умовах 2016 року встановлено спад шкідника до 39 \%. Визначено видовий склад патогенів, які розвиваються на зернівках ячменю ярого. Ураження зернівок альтернаріозом за роками коливалось в межах 9,077,0 \%, гельмінтоспоріозами - 4,0-55,0 \%, фузаріозом - 0,0-12,4\%.

Висновки. Установлено, що найбільш розповсюдженими хворобами ячменю ярого в умовах східної частини Лісостепу України є кам'яна сажка (Ustilago hordei (Pers). Lagerh.) та види гельмінтоспоріозу, які викликають плямистості листя і загнивання коренів (Drechslera teres Ito, D. graminea (Rabenh.) Shoemaker, D. Sorokiniana Subram), серед шкідників найбільш поширені шведські мухи (Oscinella frit Linnaeus i O. pusilla Meigen). Основними патогенами, які поширюються на зернівках ячменю ярого є грибні хвороби з родів Drechslera spp., Fusarium Link. та Altenararia Fries.. Розроблено два нових способи фітопатологічного аналізу поширеності хвороб на посівах ячменю ярого, один з них здійснюється шляхом осінньої сівби насіння і обліку ураженості рослин у фазі кущення, другий спосіб - фітоекспертиза насіння на зараженість збудниками хвороб шляхом пророщення зернівок у розчині сахарози.

Ключові слова: патокомплекс, ячмінь ярий, ячмінна злакова муха, вівсяна злакова муха, гельмінтоспоріозна коренева гниль, гельмінтоспоріозна плямистість листя, кам'яна сажка, альтернаріоз, фузаріоз, насіннєва інфекиія 


\section{ПАТОКОМПЛЕКС ЯЧМЕНЯ ЯРОВОГО В ВОСТОЧНОЙ ЧАСТИ ЛЕСОСТЕПИ УКРАИНЫ}

Звягинцева А.Н., Петренкова В.П., Кобызева Л.Н., Ныска И.Н., Кучеренко Е.Ю., Зуева Е.В., Васько Н.И.

Институт растениеводства имени В.Я. Юрьева НААН, Украина

Цель. Определить комплекс вредных организмов ячменя ярового и их изменчивость под влиянием гидротермических условий вегетационного периода культуры в восточной части Лесостепи Украины и усовершенствовать способы выявления видового состава болезней на растениях и зерне.

Методы. Уровень распространенности болезней и вредителей определяли согласно общепринятым и специальным методикам в соответствии к существующим шкалам оценки и методик, модифицированных нами в ходе роботы. Усовершенствовали способы определения видового состава возбудителей болезней ячменя ярового путем весеннего (оптимальный) и осеннего (имитация влажных условий) высева семян с последующим проведением учета проявления болезней в фазе кущения растений и подбором питательной среды для фитоэкспертизы зерна и определения уровня их зараженности.

Результаты. Вследствие проведения учетов по распространению болезней и вредителей на растениях ячменя ярового при разных сроках высева (осенью и весной) на протяжении 2009-2020 гг. установлено, что осенний высев семян является более эффективным способом для выявления гельминтоспориозов на ячмене яровом по сравнению с общепринятым способом весеннего сева, так как в осенний период создаются благоприятные условия для развития этого гриба. В основном патокомплекс ячменя ярового был представлен каменной головней, гельминтоспориозными пятнистостями листьев, корневыми гнилями, злаковыми мухами. Наибольшее распространение каменной головни (до 67,0 \%) отмечали в годы, когда погодные условия периода вегетации характеризировались как избыточно увлажненные $(\Gamma T К=1,7$ в 2020 г.) и слабозасушливые (ГТК=1,1 в 2015 г.). Наивысшее значение распространения гельминтоспориозных пятнистостей (100\%) отмечено в условиях достаточного увлажнения в 2014 году $(\Gamma T К=1,4)$. Численность шведских мух за период исследований находилась, в основном, на высоком уровне (до 100 \%), только в условиях 2016 года установлен спад вредителя до 38,7 \%. Определен видовой состав патогенов, развивающихся на зерновках ячменя ярового. Поражение зерновок альтернариозом по годам колебалось в пределах 9,0-77,0 \%, гельминтоспориозами - 4,0-55,0 \%, фузариозом - 0,0-12,4\%.

Выводы. Установлено, что наиболее распространенными болезнями ячменя ярового в условиях восточной части Лесостепи Украины являются каменная головня (Ustilago hordei (Pers). Lagerh.) и виды гельминтоспориоза, вызывающие пятнистости листьев и загнивание корней (Drechslera teres Ito, D. graminea (Rabenh.) Shoemaker, D. Sorokiniana Subram), среди вредителей наиболее распространены шведские мухи (Oscinella frit Linnaeus i O. pusilla Meigen). Основными патогенами, которые распространяются на зерновках ячменя ярового являются грибные болезни с родов Drechslera spp., Fusarium Link. и Altenararia Fries. Разработаны два новых способа фитопатологического анализа распространенности болезней на посевах ячменя ярового, один из них осуществляется путем осеннего сева семян и учета пораженности растений в фазе кущения, второй способ - фитоэкспертиза семян на пораженность возбудителями болезней путем проращивания зерновок в растворе сахарозы.

Ключевые слова: патокомплекс, ячмень яровой, ячменная злаковая муха, овсяная злаковая муха, гельминтоспориозная корневая гниль, гельминтоспориозная пятнистость листьев, каменная головня, альтернариоз, фузариоз, семенная инфекция. 


\section{PATHOGENIC ORGANISMS ON SPRING BARLEY IN THE EASTERN FOREST-STEPPE OF UKRAINE}

Zviahintseva A.M., Petrenkova V.P., Kobyzeva L.N., Nyska I.M., Kucherenko Ye.Yu., Zuieva K.V., Vasko N.I.

Plant Production Institute named after V.Ya. Yuriev NAAS, Ukraine

Purpose. To detect harmful organisms on spring barley and their variability under the influence of hydrothermal conditions during the crop vegetation period in the Eastern Forest-Steppe of Ukraine and to improve methods of pathogen detecting on plants and grains.

Material and methods. The prevalence of diseases and pests was determined by conventional and special methods in accordance with the existing assessment scales and by methods modified by us in the course of work. We improved methods for determining pathogenic species on spring barley upon spring (optimal) and autumn (simulation of wet conditions) sowing followed by evaluating the disease signs during the tillering phase of plants and selecting nutrient medium for phytoexamination of grain and assessment of its infection rate.

Results and discussion. The 2009-2020 assessments of the prevalence of diseases and pests on spring barley plants from seeds sown on different dates (autumn and spring) showed that the autumn sowing was more effective for barley net blotch manifestation on spring barley compared to the conventional method of spring sowing, since the autumn conditions are favorable for development of this fungus. Pathogens on spring barley were mainly represented by head smut (Ustilago hordei), barley leaf stripe disease, root rots and corn flies. The greatest prevalence of head smut (up to 67.0\%) was observed in the years when the weather was excessively humid during the growing period ( $\mathrm{HTC}=1.7$ in 2020) or slightly arid (HTC $=1.1$ in 2015). The greatest spread of barley net blotch (100\%) was observed on sufficient water supply in 2014 (HTC = 1.4). The numbers of frit flies during the study period were significant (up to $100 \%$ ), only in 2016 there was a decline to $39 \%$. The pathogen species that develop on spring barley seeds were determined. Alternaria contamination of grain ranged 9.0 to $77.0 \%$ from year to year; Drechslera contamination - 4.0 to $55.0 \%$, Fusarium contamination - 0.0 to $12.4 \%$.

Conclusions. Head smut (Ustilago hordei (Pers. Lagerh.)) and Drechslera fungi causing leaf blotch and root rot (Drechslera teres Ito, D. graminea (Rabenh.) Shoemaker, D. sorokiniana Subram) were found to be the most common diseases of spring barley in the Eastern ForestSteppe of Ukraine. Of pests, frit flies (Oscinella frit Linnaeus and O. pusilla Meigen) were most common. Major diseases of spring barley seeds are of fungal etiology (genera Drechslera spp., Fusarium Link. and Altenararia Fries). Two new methods of phytopathological analysis of the prevalence of diseases on spring barley crops have been developed: one of them is carried out by autumn sowing of seeds and evaluating plant damage during the tillering phase; the second method is phytoexamination of seeds for pathogens via germination of caryopses in sucrose solution.

Key words: pathogens, spring barley, barley frit fly, oat frit fly, Drechslera root rot, barley leaf stripe disease, head smut, alternaria leaf spot, Fusarium rot, seed infection 